\title{
FGFR2 NP_000132.3:p.C382R
}

National Cancer Institute

\section{Source}

National Cancer Institute. FGFR2 NP 000132.3:p.C382R. NCI Thesaurus. Code C107597.

A change in the amino acid residue at position 382 in the fibroblast growth factor receptor 2 protein where cysteine has been replaced by arginine. 